\title{
Gender and conservation agriculture: constraints and opportunities in the Philippines
}

\author{
Mary Harman Parks • Maria Elisa Christie • \\ Isidra Bagares
}

Published online: 1 February 2014

(C) The Author(s) 2014. This article is published with open access at Springerlink.com

\begin{abstract}
This research identifies gender-based constraints and opportunities for the adoption of conservation agriculture production systems based on a casestudy with smallholder farmers in two villages in Misamis Oriental, Northern Mindanao, Philippines. Using a livelihoods framework, we explore gendered dimensions of access to assets or resources, agricultural practices, and knowledge and perceptions in the context of food security and soil conservation. Our mixed methods approach includes focus group discussions, household interviews, participatory mapping, and GPS mapping. We found that men and women have different access to assets, gender roles, and soil perceptions that could have implications for whether farmers adopt conservation agriculture (CA) in the Philippines. This paper also discusses how development activities like CA could affect gender relations in a site-specific context and provides
\end{abstract}

\footnotetext{
M. Harman Parks $(\bowtie) \cdot$ M. E. Christie

Office of International Research, Education, and

Development (OIRED), Virginia Tech, 526 Prices Fork

Road, Blacksburg, VA 24060, USA

e-mail: harmanm2@vt.edu

M. E. Christie

e-mail: mechristie@vt.edu

I. Bagares

ICRAF Research Site, 9004 Claveria Misamis Oriental,

Mindanao, Philippines

e-mail: isbbagares@yahoo.com
}

recommendations for increasing gender equity and the likelihood of adoption.

Keywords Gender $\cdot$ Soils $\cdot$ Conservation agriculture $\cdot$ Philippines $\cdot$ Livelihood strategies

\section{Introduction}

Degraded landscapes and unsustainable agricultural practices are prevalent throughout the world and can heighten food insecurity and poverty rates (FAO 2011). Smallholder farmers are especially vulnerable and more likely to implement unsustainable agricultural systems due to their dependence on crop production and susceptibility to economic shocks (Barrett 2002). Scientists are exploring how conservation agriculture (CA) principles and practices can reverse these trends. Yet, changes in farming systems impact men's and women's assets such as time, resources, and labor (Doss and Morris 2000). Despite the fact that women make up nearly half the agricultural labor force, in many developing countries, their roles in farming communities go unnoticed and they are less likely to participate in training and extension services (World Bank 2009; FAO 2011). It is necessary for development programs to understand women's perceptions, priorities, and concerns because these may differ from men's and can affect outcomes. 
These programs should take into account how gender ${ }^{1}$ relations influence a program and how a program's activities influence gender relations.

Conservation agriculture is a means to increased agricultural productivity, food security, and soil quality according to the United Nations Food and Agriculture Organization (FAO). It is made up of three components: (1) maintaining year-round crop-cover, including intercrops or mulch from previous crops; (2) exercising no or minimum tillage to reduce soil disturbance, thereby keeping the soil structure the same and reducing erosion; and (3) diversifying crop rotations by including adapted and appropriate crops to maintain biodiversity, contribute nitrogen, and avoid pest infestations. CA has potential to address many of the problems faced by smallholder farmers such as degrading soil quality and decreasing yields and incomes (Hobbs 2007; Knowler and Bradshaw 2007; Hobbs et al. 2008; Kassam et al. 2009; Derpsch et al. 2010). CA can also reduce labor burdens and time between harvests in the long-term (Knowler and Bradshaw 2007; Kassam et al. 2009). It has demonstrated resilience to climate variability due to the higher soil infiltration, which minimizes the impacts of flooding and erosion (Hobbs et al. 2008). Along with these benefits, CA can increase the overall sustainability of land and enhance food security (Derpsch et al. 2010).

There are costs and constraints to CA adoption, however. Government subsidies are a major reason why farmers adopt CA, yet this can result in dependent farmers (Giller 2009). The increased presence of weeds in the first several years of adoption can lead to labor constraints. Many farmers do not have access to the machinery required for planting, training to learn the techniques, or inputs required in early stages such as herbicides and pesticides. Land tenure insecurity is also prevalent in the Philippines due to frequent redistribution under the agrarian reform (Olano 2002) and has been found to be a factor in farmers' decisions to not adopt CA in many studies since most benefits are delayed (Soule et al. 2000; Gebremedhin and Swinton 2003; Knowler and Bradshaw 2007). Furthermore, the short-term benefits are variable (Giller 2009) and there are mixed findings of whether CA is

\footnotetext{
${ }^{1}$ Gender refers to the social construction of what is expected of, allowed, and valued in a man or woman in a given culture, context, time, and/or location.
}

economically viable and socially acceptable for smallholder farmers.

Agriculture in Southeast Asia is characterized by smallholder farms where their production makes up the majority of the economic output and significantly affects food security (IFAD 2009). According to Cramb (2001), smallholder agriculture is also a major factor in soil erosion in the Philippines, which is regarded as one of the country's most serious environmental problems. In 2009, it was estimated that farmers worldwide grew 206 million hectares of arable crops under CA (Kassam et al. 2009). However, Southeast Asia has seen only marginal adoption in part because its main crop, rice, is usually grown under a tillage system (Kassam et al. 2009). Furthermore, there is little research on the role of smallholders' livelihoods and overall gender-specific impacts of CA in Southeast Asia.

The Feed the Future Innovation Lab for Collaborative Research on Sustainable Agriculture and Natural Resource Management (SANREM), funded by the U. S. Agency for International Development (USAID), has been carrying out research in the Philippines since 1994. Beginning in 2009, it has been working in Claveria, a municipality in Northern Mindanao, focusing on CA. In partnership with the International Centre for Research on Agroforestry (ICRAF-World Agroforestry Centre), SANREM works with 15 households in Claveria implementing CA experiments. The program is working in 13 other countries with the goal of learning general lessons about CA from specific experiences on the ground. One of SANREM's research initiatives seeks to identify gender issues relevant to CA through collaboration with individual regional programs.

This study uses a livelihoods approach and the gender dimensions framework (GDF) (Rubin et al. 2009) to identify gender aspects for the Philippines site. A livelihoods framework considers peoples' assets, strategies, and outcomes to recognize and highlight all the components that contribute to a household's livelihood (Bebbington 1999; Ellis 2000; Allison and Ellis 2001; Oberhauser et al. 2004). There is still a need for empirical evidence of gendered practices and adaptive strategies for development (Allison and Ellis 2001; Oberhauser et al. 2004) and implementation of soil management in food-insecure countries. According to Valdivia and Gilles (2001), gender relations need to be understood in terms of how 
they affect rural families and their livelihoods since this "may result in great losses to the environment and society" (p. 8). We aim to understand how gender plays a role in the way rural families negotiate livelihoods and how these affect farmers' ability to adopt CA. To identify gender-based constraints and opportunities that may affect the success of CA, we use the four overlapping categories of the GDF: (1) access to and control over assets (tangible and intangible); (2) beliefs and perceptions; (3) practices and participation, and (4) laws, legal rights, and institutions. The dimensions also include the crosscutting dimension of power. This framework along with a livelihoods approach helped develop our research question: do men and women have different access to assets or resources, agricultural practices, and knowledge and perceptions of soils that could affect their participation in CAPS?

This study also draws on feminist political ecology (FPE), a sub-field in the discipline of geography. FPE is the study of how gender relations influence or are influenced by ecological and/or political landscapes, particularly in the context of development (Rocheleau et al. 1996a, b). FPE explores how men's and women's social roles impact land management, resource use, and livelihood strategies. Gendered and local knowledge are important in determining men's and women's different roles, priorities, practices, and decisionmaking processes in the context of environmental issues and changes (Rocheleau et al. 1996b; Udry 1996; Mohanty 2003; Momsen 2010). Knowledge is also a key asset for land management and CA. FPE argues that access to assets is gendered, as are rights to and responsibilities for resource production and maintenance (Rocheleau et al. 1996a), with women's access being indirect and less independent (Rocheleau and Edmunds 1997). FPE highlights the importance of including both men and women in development research as well as increasing women's visibility in natural resource management.

\section{Study site}

Our study site is in Claveria, a land-locked municipality in the province of Misamis Oriental in northern Mindanao, Philippines. Claveria consists of 24 barangays, or villages. Two of these were selected for this research: Rizal and Patrocenio (Fig. 1).
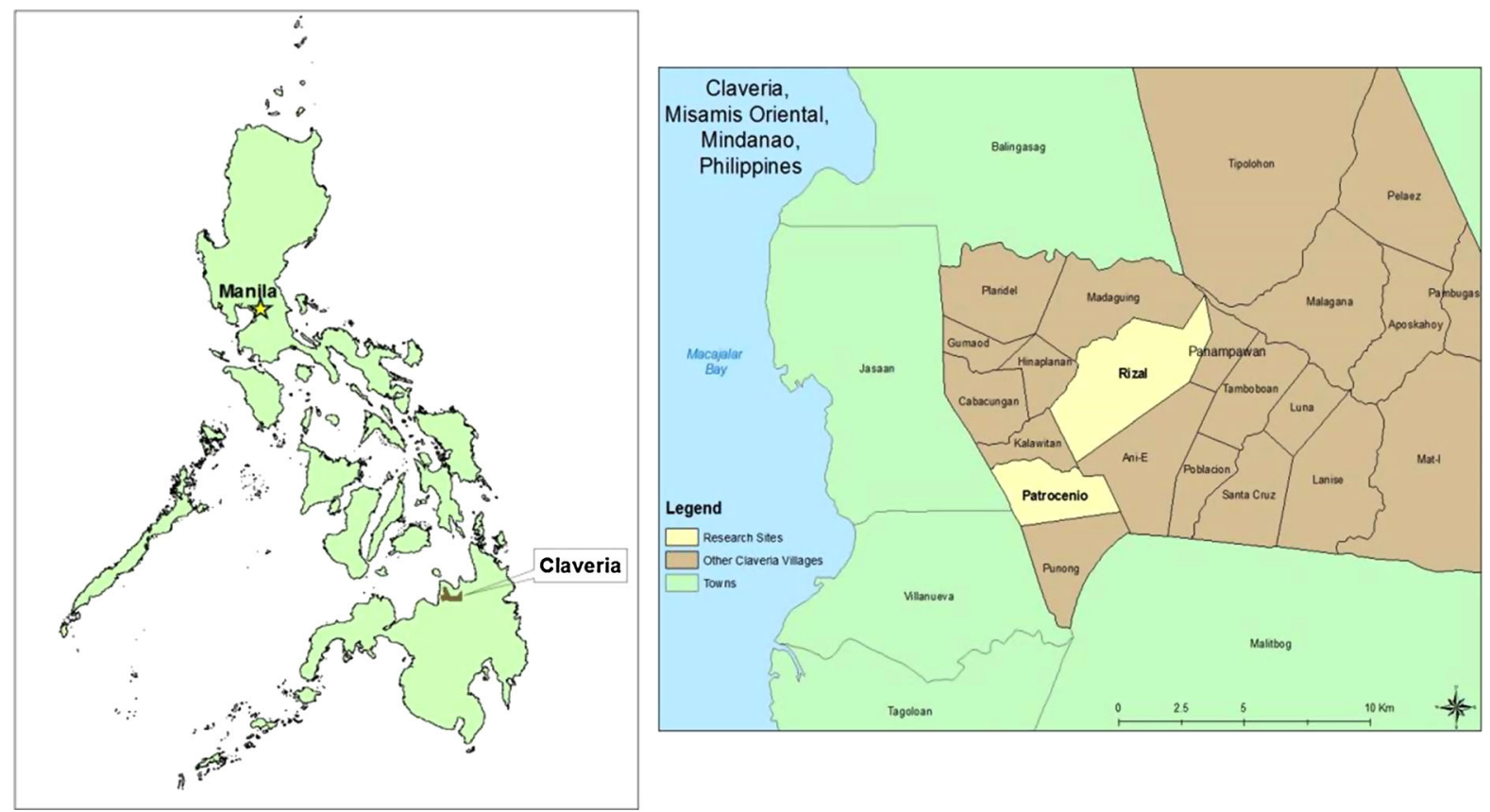

Fig. 1 Map displaying the two research sites, Rizal and Patrocenio, located in the municipality of Claveria in northern Mindanao, Philippines 
These two villages met our criteria for site selection: (1) safety; (2) accessibility; (3) relevance (agricultural community); (4) average farm size ( $<1$ acre); and (5) availability of secondary GIS data, particularly satellite imagery with little cloud cover. They lie on a rolling plateau with elevations ranging from 350 to $950 \mathrm{~m}$ above sea level. Claveria suffers from degraded landscapes due to soil erosion and poverty. The soils are classified as acidic upland soils and the average soil erosion rate is $200-350 \mathrm{mg} \mathrm{ha}^{-1}$ annually (Mercado Jr. et al. 2010). Despite poor soils, this area supports a community of smallholder farmers that practice commercial and subsistence farming. The dominant crops are maize, upland rice, sweet potato, vegetables, and cassava. In Claveria, we observed soil conservation methods including contour farming and agroforestry, though these were not generally practiced by participants in this research.

The study population consists of smallholder farmers in the two villages. The local population primarily speaks Bisaya and their main economic activity is farming. Based on a survey conducted by the Claveria Municipal Nutrition Action Office in 2011, Rizal has a population of 1,053 with 220 households and Patrocenio has a population of 3,504 with 746 households. According to Delgado and Canters (2011), farmers in Claveria are generally poor and "over $50 \%$ subsist below the provincial poverty threshold" (p. 171). The two villages do not have paved roads and have limited access to potable water. Few households have electricity.

\section{Field methods}

Fieldwork took place primarily during three visits to the Philippines: 1 week in February 2012 to pretest the methodology and carry out preliminary research; 7 weeks in July and August of 2012 for the bulk of the activities; and 1 week in January 2013 for restitution and validation of results. We employed

Table 1 Number of participants by gender

\begin{tabular}{llll}
\hline & Men & Women & Total \\
\hline Focus group discussions & 21 & 26 & 47 \\
Household interviews & 18 & 18 & 36 \\
Total & 39 & 44 & 83 \\
\hline
\end{tabular}

both qualitative and quantitative methods consisting primarily of participatory exercises during focus group discussions (FGDs), household interviews, and visits to farmers' fields.

There were 83 participants in this research, 40 from Rizal and 43 from Patrocenio. The people involved in the FGDs were different from those in the household interviews (Table 1).

We interviewed people from a total of 19 households. Seventeen of those households included one adult male and one adult female, whom we interviewed separately. The other two households included one widow and one widower. Nine of the households were in Rizal and ten were in Patrocenio. We also conducted one key informant interview with the leader of a women's association and several days of participant observation on farms.

We used different sampling methods to select participants for the FGDs and the household interviews. For the FGDs we used a convenience method (Marshall 1996) where farmers who visited the barangay halls received invitations. Although this was a useful recruitment method, it did raise issues of sample bias. For the household interviews, we obtained a list of the population from the Municipality and randomized the names in Excel. Then, with the assistance of barangay staff and going down the list one name at a time, we stratified the sample to eliminate anyone who did not meet the following criteria: they were a smallholder farmer (even if they also worked as hired labor); they were married with an adult man and woman in the household (except for the widow and widower which we purposely selected); they did not attend one of our FGDs; and they had not previously participated in any SANREM activities. Our local support team played a crucial role as facilitators, note-takers, and observers in the FGDs, and with interpretation, note-taking, and transcription of the household visits. Besides helping bridge linguistic and cultural barriers, their familiarity with the research population created a friendly and welcoming atmosphere for our repeated visits.

The FGDs consisted of two parts, one regarding local soil knowledge, beliefs, and perceptions, and the other on community practices. The first part of the FGD consisted of the following: a discussion of "what is soil?"; descriptions of local soil samples; listing local soil quality indicators; listing different community soils; and mapping these on a satellite image. In the 
second part of the FGD, farmers worked with facilitators to develop a chart of socio-economic activities and a timeline of changes relevant to agriculture and gender. At the conclusion of activities, the men's and women's group presented their work to each other.

The 36 semi-structured, household interviews included participants ranging from 30 to 77 years of age. The women had slightly more formal education than the men. All except one woman had at least 5 years of elementary education: five completed the second or third year of high school; three graduated high school; and two entered college level. Of the men, all but three had graduated elementary school, while two completed the second year of high school, and seven graduated high school. Generally, the husbands were older than the wives and the younger the person was the more likely he or she had more education due to the increasing emphasis on school attendance in the Philippines.

The interviews began with the collection of demographic information and farming history, and continued with the following: a photo interpretation exercise; description of local soil samples; participatory mapping with farmers drawing resources and activities on their farm needed for their livelihood and labeled who (men or women) has access to, control over, and provides labor (indicated by ACL) ${ }^{2}$ for each. They also drew agricultural practices, animals, and soils associated with those spaces, mapped household and community soils on a satellite image, and described changes in climate and agricultural practices. After the household interviews, we asked the participants if we could visit their farm. During the field visits we obtained area calculations of the entire farm using a hand-held GPS unit and calculated the areas of the best and worst soils that the husband and wife had chosen during the household interview.

A final FGD was conducted in January of 2013 with the participants of the household interviews to provide restitution to the farmers and team involved during the previous fieldwork. This included presenting findings from the interviews to ground-truth results, soil analysis results, and Google Earth maps with the GPS data of the house and farm. We also asked participants additional questions in gender-segregated groups. ICRAF also made several presentations on CA

\footnotetext{
${ }^{2}$ Access is the ability to use and benefit from a resource; control is the power and/or ownership of a resource, and labor is the work provided in relation to that resource.
}

and distributed seeds to the farmers to test new crop covers. The half-day event provided an opportunity for discussion and allowed the farmers to ask questions.

\section{Data analysis}

The data from the FGDs and household interviews were recorded on flip chart pages and written reports containing notes, observations, and reflections from each team member. These were translated and transcribed along with the audio-recorded interviews to help us understand the context and meanings not readily accessible to outsiders. Using Microsoft Word, we incorporated the data from each exercise into charts and disaggregated by village and gender. This allowed us to compare the responses of men and women from each village and determine similarities and differences. Once we analyzed the data, we categorized them based on the GDF and designated them as either gender-based constraints or opportunities for CAPS.

To analyze the geospatial data from the household interviews and FGDs, we incorporated photos of the FGD maps and household satellite maps into Google Earth and GIS. In Google Earth, we geo-referenced the photos and digitized each polygon in each map using the photo overlay tool. We converted the polygons to shapefiles in Arcmap 10, and then merged them based on gender and village for the FGD maps, and based on household and village for the household field visits. Maps were created to layer the men's and women's local community soils drawn during the FGDs, particularly the names of the soils and the best and worst soils, both distinguishable by gender. The GPS data from the field visits were also imported into Google Earth and Arcmap 10. We created maps to display the soils labeled by household, spouse, and whether it was designated as best or worst soil. They were then analyzed qualitatively by visually observing similarities and differences between other attributes such as soil locations, land use, soil names, and soil quality indicators. We also analyzed all of these attributes by gender.

\section{Results}

This research found that access to assets, agricultural practices, and soil knowledge and perceptions are 
gendered in Claveria and may impact receptivity to CAPS. Men and women have different access to assets, particularly to land and training. There is a gendered division of labor in this region with men working mainly on the farm and women mainly in the home. While there are differences in men's and women's soils knowledge and perceptions, there are also similarities such as using plant growth as a soil quality indicator and the perception that local soils are degrading. We also found that topography influences gender roles, agricultural practices, and soil perceptions.

\section{Land}

In our sample, women do not own land as often as men; they generally obtain or access land through their husbands. There were four different ways people claimed to access land: (1) inheriting from the husband's or wife's parents; (2) "mortgaging;"3 (3) cultivating family or friends' land with permission; or (4) applying for land through the Certificate of Land Ownership Award (CLOA) Program. ${ }^{4}$ In eight of the households the land was inherited from the husband's parents. Five applied for land from the CLOA program and all were granted titles. Four obtained land through family or friends and two inherited land from the wife's parents. Of the households that inherited land from the husband's parents, half of the wives said they did not own land. In those that applied to the CLOA program, the husband was the one who applied for the land title. In the case of households that accrued land through family and friends, it was the husband's family or friend that gave them land. Finally, of the two households that inherited land through the wife's parents, one was going to put the title in the husband's name. In Claveria, when a woman inherits land, the title usually goes in the husband's name because he is considered head of the household. As a result, women's access to land is dependent on their

\footnotetext{
3 An informal land agreement where a farmer pays a specific sum for land to the landowner for a certain amount of time such as 1-5 years. When the agreement "expires" the landowner must repay the renter the amount paid during time on the land. If the owner cannot pay, the farmer can continue to farm on the land until they are reimbursed by the owner.

4 This program is part of the Comprehensive Agrarian Reform Law (CARL) that was established in 1988. The goal of CARL was to distribute land to landless farmers and farm workers and provide support services regarding tenure.
}

relationship with men. One woman farmer said: "It does not matter who inherits or obtains [the land], it goes in one name, and that's usually the husband. I do not own land, but my husband does, so that's how I get land" (July 23, 2013).

While women are legally allowed to own land, local attitudes and policies limit women's access to land and generally males are the ones who apply for and are awarded land. Several farmers told us that in order to be granted land under the CLOA, one must have no other source of income besides farming, while women commonly have businesses in addition to farming. A person must have been farming a particular piece of land for 5 years or more to be eligible for obtaining the title to it, and they must pay all the taxes and surveys on the land. These last two qualifications are difficult for women to meet because they have additional responsibilities which limit their time farming and it is difficult for women to access credit to pay the initial fees.

Access to pastureland is also complex. Thirteen out of the 18 men claimed there were changes in pasturing practices. Most of the farmers said they now pasture on their own land partly because an ordinance had been passed recently that restricts them from pasturing on other peoples' land. The trigger for the ordinance was farmers' complaints that other people's animals destroyed their crops or had eaten all their grass. Some men found this ordinance particularly constraining because they had to reduce their cultivation space to make room for pastureland and watch the animals or tie them up so they would not damage crops. Thus while the ordinance aims to reduce conflict over pastureland, it increases competition between cultivation and grazing space on individual farmers' land. According to one male farmer, "We have to pasture on our own land now because of [the ordinance]. I had to cut down on maize and plant grass there. And now the common pastureland has too many cows and no grasses" (July 18, 2013).

\section{Training}

Women do not have the same access to training as men. During the interviews, we asked farmers if they ever attended agricultural workshops or seminars. Of the 18 men interviewed, 14 of them claimed they had. Conversely, only four of the 18 women said they had attended workshops or seminars, and those women said they attended them in place of their husband. In 
the final FGD with the household participants, most of the women reported it was the first such event to which they had been invited. This is mainly because the training or seminar hosts invite one person per household, and the head of the household usually attends. In an interview with the leader of the women's association group in Patrocenio, she explained that women not receiving training is a problem in their village: “...the husbands won't let their wives attend any trainings. We have lots of trainings, such as seeds and hog-raising, but that is a problem for the husband to let their wives go. Because only one household member should go...but the wives have to stay and care for the children" (August 5, 2012). In addition, many workshops held in the village, including CA workshops, concern land preparation, which is men's task on the farm. As a result, women are not encouraged or interested in attending.

While there are gendered constraints to women attending workshops, distance is a constraint that limits both men and women when it comes to learning about trainings and attending them. Many times when an agricultural training is to be held for a particular barangay, it is announced through the local barangay hall or center, similar to the way our FGD participants were invited. Those who frequent the centers are invited to or learn about them. Those who live even a kilometer away from these barangay centers are less likely to become aware of trainings or attend them because it is difficult for them to travel frequently. This was reported in several households we visited that were some kilometers away from the barangay halls. The men claimed that they "do not get out much because [they] live so far away" and as a result, are not often invited.

"Women don't farm": or do they?

In the household interviews, FGDs, and our own observations, we found a gendered division of labor.

Table 2 Men's and women's source of income outside of farming their own land

\begin{tabular}{lcl}
\hline & Men & Women \\
\hline Hired labor & 11 & 4 \\
Barangay official & 2 & 0 \\
Sari-sari store & 0 & 4 \\
Medicine/health official & 0 & 2 \\
Food/restaurant & 0 & 1 \\
\hline
\end{tabular}

In addition to farming their own land, men hold positions in the local government as barangay officials and work on other farms for pay, mainly tilling. Some women also work as hired labor on farms planting, weeding, and harvesting, but they mainly work in their own businesses, including sari-sari stores (convenience stores run out of their home) or restaurants, and healthcare positions (Table 2).

Women are also primarily responsible ${ }^{5}$ for the household chores including cooking, cleaning, washing, and taking care of children. This division of labor was linked to a gendered decision-making dynamic. In the participatory mapping exercises, the participants claimed that in addition to labor, women have complete access to and control of the household, but most of the men only have access and no decisionmaking authority over the household. Furthermore, they reported men have full access to and control of the farm, while the women have access, some control, and sometimes provide labor to certain plots (Figs 2, 3). She has ACL in the corn because it is on flat land closer to the house. She drew a house with stairs and stilts and said she has ACL in it while her husband only has access. Her banana cue business (sugar-coated fried bananas served on a stick) is represented on the side and illustrates another livelihood strategy that contributes to the household. She drew cows and chickens at the bottom: she has ACL with the cows only when the husband is away, while she always has ACL with the chickens.

The crop on the left is the corn which has good soil, indicated by the OT for "tambok" (fertile). The plot to the right is where they grow cassava and which he considers bad soil because it is "da-ot" (acidic). He also mentioned how his farm is contoured and rather than chickens, he drew the family duck, Pato.

This finding leads us to ask to what extent women farm. In the interviews, most of the women claimed they work on the farm between 5 and $6 \mathrm{~h}$ a day and/or 2-4 h on the weekends, depending on other responsibilities. Women are likely to spend less time on the farm if they have small children, businesses, unpaid community work, or their house is not located on the farm. The men seldom recognized women's participation on the farm in the FGDs and interviews. One farmer said, "Woman tend to [do] more household and

\footnotetext{
5 Primary responsibility means an activity that is fundamental to, required, or expected of an individual.
} 
Fig. 2 Woman's participatory map from Patrocenio showing the farm where her family grows corn and cassava

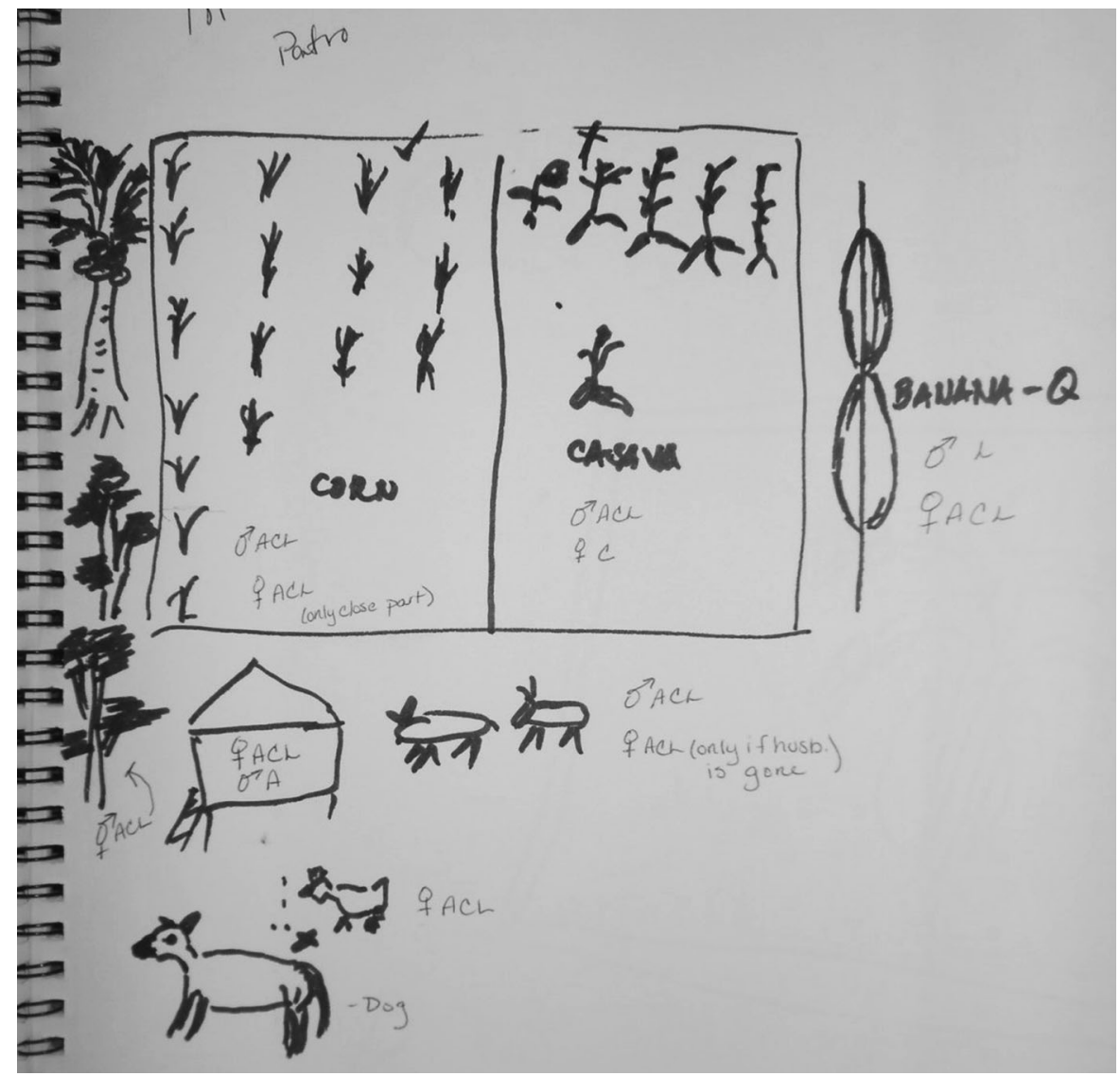

community activities rather than do farming activities" (January 26, 2013). Women did name several farm activities in which they participate but are not necessarily responsible for, such as planting and harvesting. Many women also reported that they are primarily responsible for weeding. In the FGDs, they listed planting flowers, raising pigs and chickens, bagging, tying, and staking as primarily women's activities. Furthermore, women are primarily responsible for selling surplus production and purchasing inputs, especially fertilizer. Thus, despite the fact that women do not always work on the farm as much as men, they play a crucial role in the farming household.

According to the farmers, this gendered division of labor benefits the farming household because it compensates for the lack of steady capital and ensures the work gets done. The farmers consider women's roles as multi-taskers and men's full time jobs as farmers as complementary by providing dual incomes and food. One woman said, "If [women] can engage in business, women can still work and manage the home." One man said, "If women are in business...daily needs can be sustained because farming takes time before [providing] a substantial income, [and] we can make ends meet" (January 26, 2013). Thus, diverse and gendered livelihood strategies are a way farmers have adapted to "having no capital," something 25 out of the 36 farmers claimed was their biggest challenge in farming.

\section{Topography and livestock}

All interviewees and FGD participants reported that men are solely responsible for land preparation activities such as plowing, furrowing, and harrowing. Farmers till their land multiple times for a single planting season and have been doing so for generations. Furthermore, all farmers interviewed said tilling the land is necessary for good production. For example, one man said, "If you do not plow, the soil is hard, the seed won't grow, and you will fail" (July 16, 2012). 


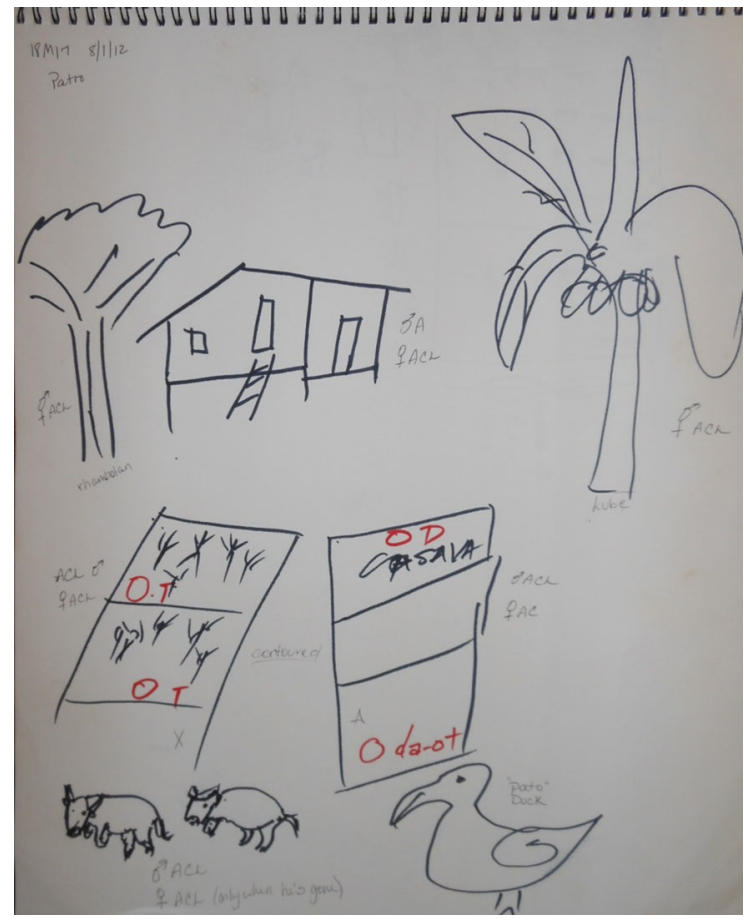

Fig. 3 Man's participatory map from the same household in Patrocenio showing many of the same gendered resources as his wife's map in Fig. 2

Farmers mainly use animals such as cows and carabaos to prepare the land for planting. This is due to the steep topography of the region that makes tractors unsafe or impractical. In several plots we visited, the slopes were as steep as $70 \%$. Plowing these landscapes with large animals can make farming difficult and requires great physical strength. In the FGDs and interviews, farmers reported that this "heavy" work is men's primary responsibility because they are stronger than women. In the final FGD, all participants confirmed men work more on sloping land than women, and stated that women generally work only on flat land because it is easier, women are afraid to fall on steep land, and it would take them longer than men to complete the work there.

Topography and farmers' perceptions of strength are linked to gendered spaces, assets, and roles. Since men have strength and access to large animals, their space is the farm, including the steep terrain. In contrast, women generally work in the home, business space, or house-lot and their gendered assets are the merchandise and smaller animals. During the participatory mapping exercise, both men and women showed that men have access, control, and labor over the cows and carabao while the women have access, control, and labor over the chickens, pigs, and goats. In fact, most of the participants claimed that women do not have access, control, or work with cows or carabao unless the husband is away (Figs. 2, 3). When we asked why, the farmers said the chickens, pigs, and goats are usually considered house-lot animals and are easy to control, thus they are part of women's livelihoods.

\section{Soils knowledge and perceptions}

In Claveria, local perceptions of soil are informed by many factors. Plant growth is considered an important indicator of soil quality. Both men and women believe soil is good or productive if there is plant growth, whether crops or grass. Most of the participants in the interviews used plant growth to indicate their best and worst soils on their farms. They also used plant growth on the satellite images to help distinguish soil types in the community. Some smallholder farmers even decide what and where to plant based on how well the land produced vegetation prior to planting.

Though plant growth was a major soil quality indicator for both men and women, there were gender differences in the types of crops that men and women discussed during the soils activities in the interviews. In both discussions of off-farm and on-farm soils, the men chose very few types of crops that could or do grow in good soil types, while women associated a variety of crops with the same. For example, men chose maize, rubber trees, and pastureland for their best soil. This parallels our observation that they mainly work with and talk about larger crops such as maize, and trees. They also work in pastureland much of the day. Conversely, women's best soils had various types of crops, mainly maize and assorted vegetables. Vegetables are usually smaller crops which contribute to household consumption, something for which women are responsible. They are also primarily responsible for selling the portion that is marketed. The most common crop associated with the worst soil was maize for both men and women. Thus, maize was the primary crop grown on both best and worst soil. After maize, the most common land use type for worst soil designated by men was the house-lot, while women designated the pasture area; these areas of soil happen to be where they do not work or spend the least amount of time. 


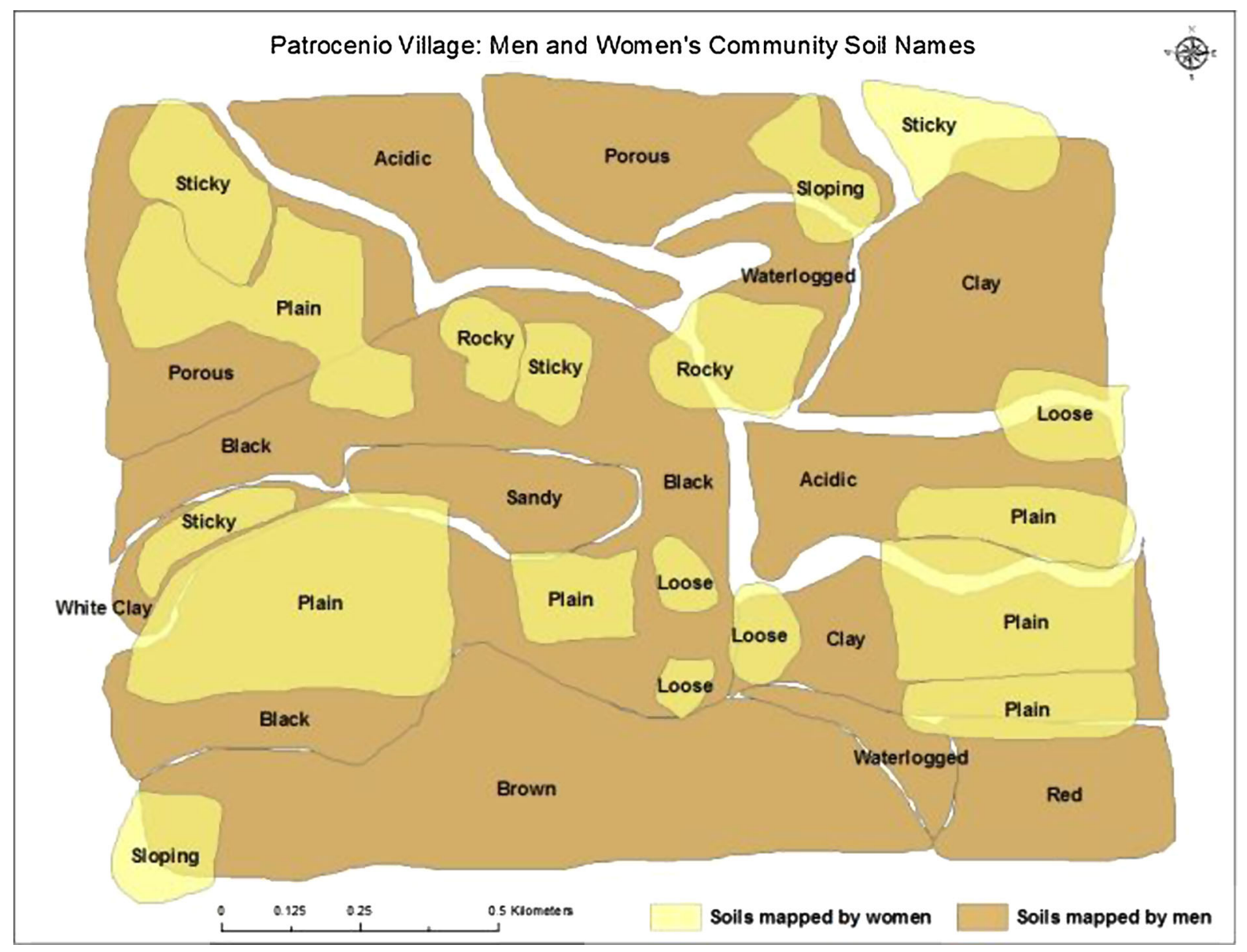

Fig. 4 Map of men and women's community soil names in Patrocenio shows the names and locations of soils the men and women drew in the FGD. Concerning topography, the women mainly mapped "plain" or flat soil where they generally work

Topography was another variable in men's and women's soil knowledge and perceptions. Flat soil was perceived by both men and women as good while steep soil was considered bad. Women mentioned more good soil than bad soil during both the FGDs and household interviews. During the household visits, two women claimed they did not have any bad soil on their farm and that topography was not an indicator of good soil because they mainly work on flat areas. Conversely, men used topography more often than women to describe soil, particularly when discussing bad soil. In the community soils mapping exercise during the FGDs, the women mainly mapped flat (plain) soils (Figs. 4, 5). Their knowledge, thus, aligns with the spaces they regularly use due to their gendered livelihood activities.
The men were confident in their own knowledge of the community soils, while the women were not. When presenting their soil map, women in the Rizal FGD said they were not sure of their answers and that the men's map was probably more accurate. They said they had a "difficult time interpreting the satellite imagery and did not have first-hand experience with much of the community land like the men did" (July 10, 2012). The men and women in the households also perceived that women lack soil knowledge because "women are not always on the farm and only judge soil by plant growth and expenses" (January 26, 2013).

Despite farmer's depth of soil knowledge, most of them perceived their soils to be degrading. One male farmer said, "We have big changes in soil...the soil now needs fertilizer, unlike before" (July 16, 2012). 


\section{Rizal Village: Men and Women's Community Soil Names}

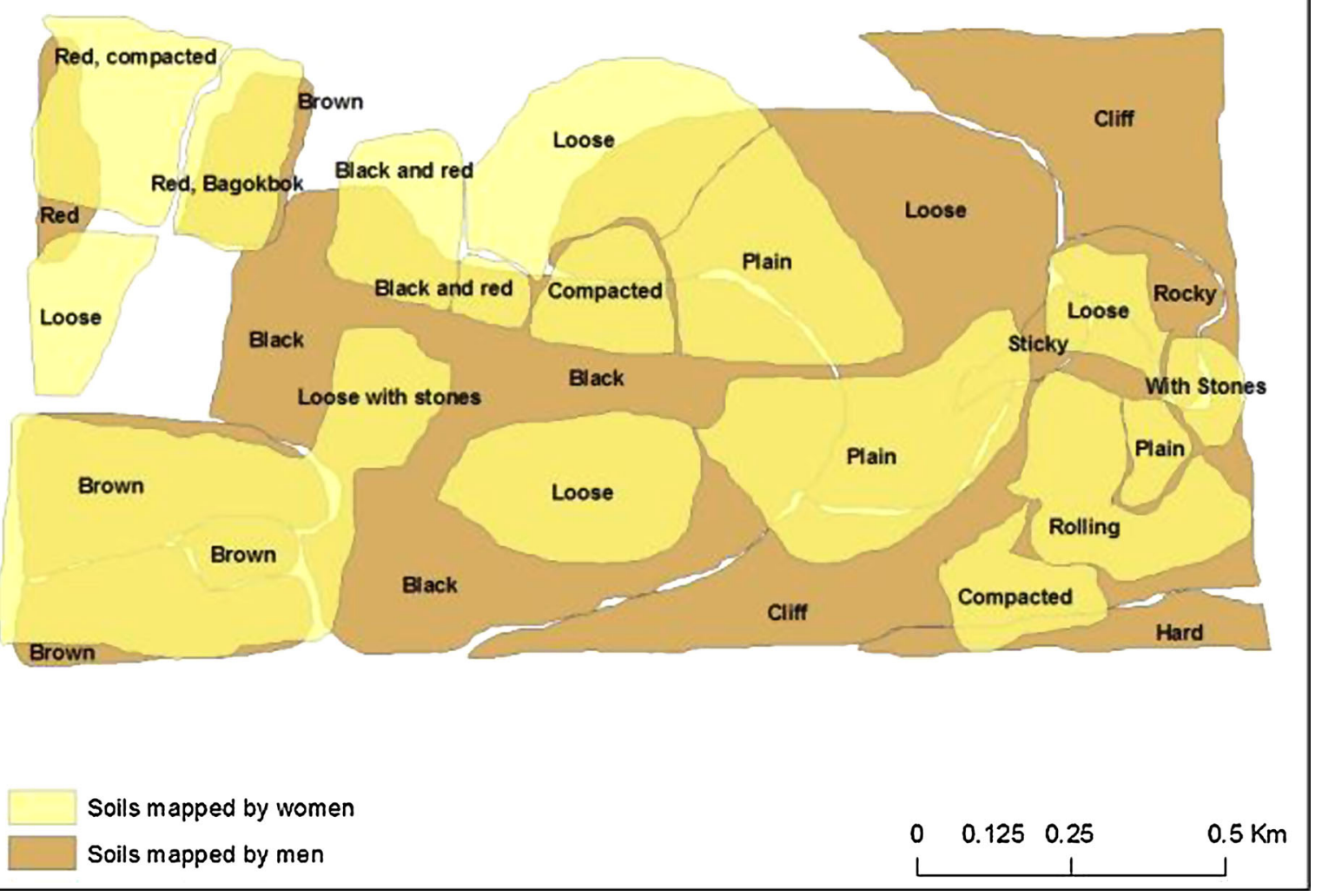

Fig. 5 Map of men and women's community soil in Rizal shows the names of soil the men and women drew in the Rizal FGD. The women labeled soils such as "plain," loose, and red. The men drew black, loose, and "cliff" or steep soils

One female farmer said, "We now have to contour our farm so our soil won't erode, which is new to us" (July 31, 2012). Other farmers also said their soils were degrading because of increased erosion, decreased yield, and changes in climate patterns. Most of the farmers were not aware of soil conservation methods other than contour farming and agroforestry. Their main way of increasing soil fertility was fertilizer application, which also was a soil quality indicator for both men and women.

\section{Discussion}

One goal of this research was to identify constraints and opportunities for the adoption of CA. In this research, men's and women's livelihoods are made up of certain assets or resources, including spaces that are modified by various components of access which in turn impact their gendered practices. These practices inform and are informed by men's and women's knowledge and perceptions. We have adapted a livelihoods framework from Ellis (2000) to include gendered components of farmers' livelihoods along with the constraints and opportunities they may experience in relation to CA (Fig. 6).

In Claveria, men's and women's perceptions and access to assets shape particular income-generating activities. Women do not have the same access to land as men and have more domestic and managerial responsibilities. This is partly due to the gendered perception that women should be more involved in non-farm labor as was found in previous research (Estudillo et al. 2001). That study states, "Farming is intensive in male labor where returns to specific experience are higher for males, whereas women tend 


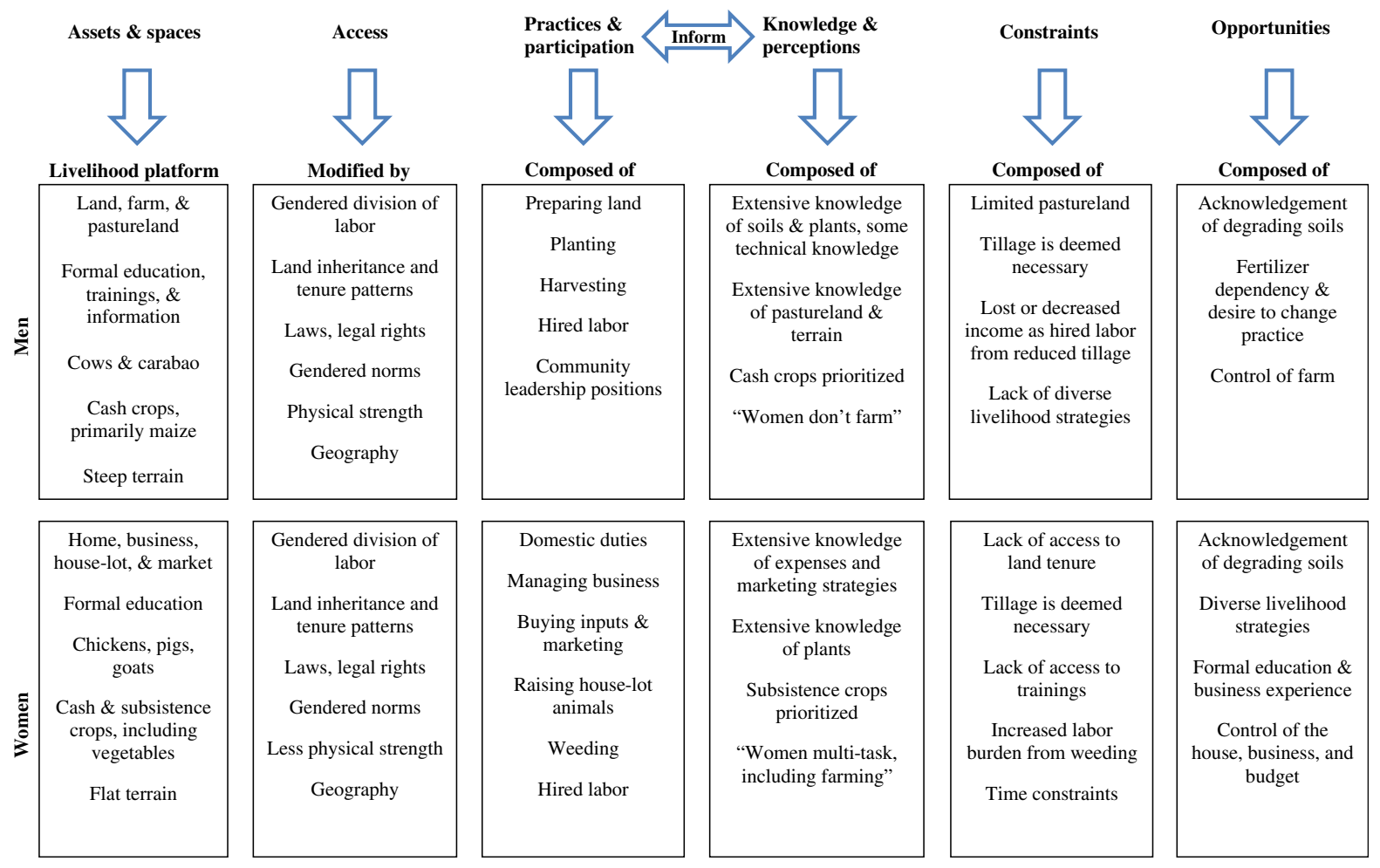

Fig. 6 Gendered livelihoods framework for conservation agriculture in Claveria (adapted from Ellis 2000, p. 30)

to receive higher returns on their education in the nonfarm sector" (p. 142). The authors also found having an uneven distribution of education and land ownership with men working on the farm and women working in business increased families' combined income in the Philippines. In other words, farmers have adapted to constraints and make the most of economic opportunities for their households.

Gendered livelihoods influence men's and women's soil knowledge and perceptions, which is important for soil conservation projects. Men's direct involvement with soil such as land preparation (e.g., tilling and planting) and women's indirect involvement with soil such as weeding, harvesting, marketing, and buying inputs could explain the similarities and differences in soil knowledge and perceptions found in this study. When deciding where to implement CA, men and women may use different soil criteria based on their gendered livelihoods. Men may be more likely to consider the color and terrain of soil since they have more technical knowledge and work on steep slopes, while the women may be more likely to consider land use or the amount of fertilizer needed.
Crop production and plant knowledge are important to both men and women in Claveria and have implications for CAPS. Men interact with the crops mainly on the farm and women mostly in the home and market. These interactions with plants, though different, suggest the importance of plant growth to both men and women when describing soils, indicating their quality, or looking at their spatial components. Exposing this type of soil knowledge and perceptions is important for conservation projects. By including gendered plant knowledge in CA research, there is the potential to further understand the interaction with the soil and plants, and men's and women's priorities, resources, and practices. This also points to the importance of acknowledging men's and women's similar knowledge of soil management and plant production, as well as differences, because both can potentially reveal new considerations for CA.

\section{Constraints}

The main gender-based constraints for CA adoption we found are lack of access to secure land tenure, 
capital, and training. Access to land could be a constraint for both men and women. According to some of the literature, resource-constrained farmers, particularly those with little access to land and inputs, are less likely to adopt CA practices (Jones 2002; Knowler and Bradshaw 2007; Giller et al. 2009). In addition, women not having access to land tenure and not being full-time farmers might pose constraints, since researchers could interpret this to mean that women's involvement is not needed in CA projects. This is significant because studies show that when women are not involved in the adoption of a (conservation) practice, it is less likely to succeed (Knowler and Bradshaw 2007; Magcale-Macandog et al. 2010).

Farmers' main concern regarding access to land is not the size of the holding. Rather, the barriers include long term access and control in the form of secure tenure and land titles. They reported that the process of obtaining titles was long, expensive, and time-consuming. Seven of the ten households that had inherited land did not obtain the titles because they felt the process was too difficult. This is a potential risk for ownership and reduces the likelihood of the farmer staying on the land or caring about long-term soil quality, which in turn, could impact CA adoption. As one male farmer said, "Ownership [of land] affects your land management because you want your land to produce long after you're gone so your children have a livelihood."

Short-term land management arrangements such as renting or mortgaging could be a constraint since there are limited benefits in the first 4 years of adoption and farmers want to maximize their profits during their tenancy. In the beginning, CA increases weeds and requires increased inputs, while not necessarily increasing yields. Farmers who are renting a plot of land for 5 years may be hesitant to adopt CA because they are more concerned about production and shortterm profits than increasing the quality of a soil that is only temporarily for their use. One female farmer said, "If the land is rented only, the farmer will just plant and make use of the land...regardless if it destroys the sustainability of the resources or not" (January 26, 2013). If land security is not addressed, it poses a significant constraint to CA adoption in the Philippines.

Limited access to capital is a gender-based constraint for CA which affects men and women differently. Initially, women could face pressure to provide more income to the household from their businesses. They also don't have the same access to credit that men do, which affects their access to land titles. Men might be challenged to replace income lost as a result of lower demand for off-farm tillage. Yet we learned there are few income-generating opportunities available to men besides farming. Farmers' concern about capital under conventional agriculture may still exist under CA if increases in capital are not observed by both men and women. According to Jones (2002), "...if capital is limiting then any conservation [agriculture] measure...is unlikely to be acceptable" (p. 1609).

Access to training has an impact on every development project. In Claveria, only one family member is usually invited to agricultural workshops. We believe there is a perception that women do not need to attend because their place is in the home and the men should attend because they are considered to be the farmer. When only husbands are invited to attend agricultural workshops, women are deprived of useful information. According to Jones (2002), the less knowledge farmers have of conservation techniques, practices, and purposes, the less likely they will support or adopt it. We submit that if women do not participate directly in these events, it is less likely that they will understand the importance of land management, sustainability, and CAPS, and that this influences household attitudes. Our finding suggests that enhancing women's agricultural training and men's entrepreneur training could benefit the farming household.

Understanding the gender divisions of labor and time allocations in communities is important to livelihoods (Niehof 2004) and CA adoption. In the short-term, CA has been shown to significantly increase the presence of weeds on the farm (Knowler and Bradshaw 2007; Giller et al. 2009). This has significant gendered impacts on farm labor in Claveria since the women are primarily responsible for weeding. CA could increase their farm labor during the first 4 years of adoption. As women have limited time available to spend on the farm due to multiple responsibilities, the fact that they are the ones who weed the farm could be a gender-based constraint for the adoption of CA. Development programs should stress the economic benefits that will eventually come with CA adoption and clarify that increased demand for labor should be temporary. 
Another gender-based constraint for CA is that men are solely responsible for land preparation. All of the participants in both the FGDs and the household interviews reported that they plow their land as part of preparation for planting. While this would seem to be an opportunity for CA because the recommended minimum tillage would reduce men's labor (Hobbs 2007), it shows that tillage is ingrained in local culture and livelihoods. In fact, $100 \%$ of the household respondents said they believe tillage is necessary to have a productive farm. Convincing farmers that minimum tillage will produce a successful crop will be the true challenge (Basch et al. 2008). Plowing is traditionally men's primary responsibility and is central to their identities as men and farmers, as well as being a main source of income for the male farmers who work as hired labor. If the men were to reduce their plowing activities, they may lose their sense of worth and contribution on the farm. Households could be economically impacted if the demand for tillage labor was reduced. Projects need to educate the farmers of the consequences tilling has on the soil and show them that minimum tillage is environmentally and economically beneficial, if only in the long run.

\section{Opportunities}

The CA literature tells us that farmers acknowledging that soils and landscapes are degrading presents one of the main opportunities for CA (Jones 2002; Hobbs 2007; Knowler and Bradshaw 2007; Giller et al. 2009). We found that farmers see soil erosion and degradation on their farms and feel they should act to reverse long-term damage. They are all aware of the importance of soil as a source of livelihood and life. The majority of the men understand that soil can suffer varying degrees of losses such as erosion and infertility. They discussed their role in taking care of soil, and the importance of nurturing it so as to use it for cultivation and income. The women also noted the importance of soil, but they looked at it through its role in their lives such as providing land for the household and for future generations. This suggests gendered perspectives of soil importance through men's and women's different interactions and practices regarding soil management and their access to different types of soil. Though different, both provide gender-based opportunities for soil conservation and CA adoption.
By considering the gendered livelihood strategies of both men and women, we can better understand farmers' perceptions of long-term soil fertility and communicate its advantages to farmers.

One way farmers are coping with soil degradation is by increasing the use of fertilizers. All the households in our research site used some sort of fertilizer, organic or inorganic. This practice poses both constraints and opportunities. Fertilizer use is a common practice among conventional farmers and is not necessarily motivated by farmers thinking their soil is degrading. Most of the farmers in this study think they have to use fertilizer because their production depends upon it, but it is not clear whether they think it is improving their soil. Farmers are also uncomfortable depending on fertilizer because they know it was not needed in the past and it is not economically or environmentally sustainable. One man said, "Our soil did not used to need fertilizer to produce...now it needs it. If we don't use it, we fail" (July 23, 2012). Thus, methods that do not require them to purchase fertilizer could be very appealing. Their current use of fertilizers also suggests that farmers in this area are not completely resourceconstrained, which is an opportunity for CA adoption (Jones 2002; Knowler and Bradshaw 2007; Giller et al. 2009).

According to the literature, men and women having equal decision-making power in the household and farm provides an opportunity for CA adoption. The gendered decision-making dynamics found in this research-men primarily control the farm while the women primarily control the house-have also been found in other studies focusing on gendered control, including in the Philippines (Tisch and Paris 1994; Nazarea 1995; Estudillo et al. 2001; Eder 2006). Men and women's division of labor and decision-making are not completely independent of each other (Udry 1996). For example, farm decisions (in)directly affect the household decisions, and household decisions (in)directly impact the farm (Feldman and Welsh 1995). A wife's decision to take on a business venture could impact the labor and resources available for farming. Conversely, a husband's decision to plant one crop versus another could affect the wife's marketing strategy.

This complexity of control, decision-making, and negotiation within a household could affect farmers' decision to adopt or reject CA (Doss and Morris 2000). While we found gender differences in decision- 
making, we argue that men and women in Claveria make separate decisions for the benefit of the entire household. For example, a woman may decide to start a business to provide additional income for farm inputs while the husband decides to plant vegetables for sale and for household consumption. Even though the decision to adopt CA may seem like a purely farmrelated decision, and thus in the husband's realm, this research supports the notion that gendered decisionmaking concerning the farm and household are two parts of a whole: farmers in Claveria are well aware their decisions affect both household and farm and they decide on changes with the aim to benefit both.

\section{Conclusion}

There is a financial component embedded in the gendered access to land that affects farmers' capacity to change their agricultural practices and leads us to question the potential for CA adoption in Claveria. At the same time, farmers perceive there is a problem and some have an incentive to invest, both factors necessary for adoption. It is impossible to predict the negotiations that will take place in a household regarding changing practices, roles, and responsibilities on the farm. However, we can make an inference about whether the adoption of CA would benefit or hurt a household. Gender-based constraints and opportunities both create and reflect a complex web of assets and resources, practices, and knowledge that impact men and women's everyday life. This study shows that it is necessary to understand households' diverse livelihood strategies to increase the likelihood of CA adoption.

Conservation agriculture programs need to be aware of the multiple and gendered knowledge and perceptions of soil in a specific site, how project activities may impact gendered livelihoods, and how these in turn may impact the adoption of CAPS. This research hypothesized the existence of gender differences in access to assets, agricultural practices, and soil knowledge relevant to CA. We showed how the intersection of a gender analysis framework with a livelihoods approach can identify issues that may impact the success of a CA project. If both men and women are not included in research-for-development, parts of the story are left out that could be significant to the implementation of a project. By including local participation and potential stakeholders in this research we are able to make recommendations for CA projects that aim to improve livelihoods by increasing gender equity, improving soil quality, and increasing agricultural productivity.

To increase stakeholder participation, including both men and women who are more secluded geographically and socially, we recommend going beyond handing out invitations to people at the barangay halls. Distributing paper invitations and posting announcements of workshops, demonstrations, and other events at basketball courts outside of the village center presents opportunities because these are important social spaces for both men and women: men use it as a recreation space and women use it for space to dry grains. It is also necessary to challenge the perception that women are not farmers and explicitly invite them to trainings along with husbands. Women should be included in CA activities because they are directly and indirectly involved in farming. CA projects could also include additional content in their trainings beyond the three components of minimum tillage, year-round crop cover, and diverse crop rotation, which may not be applicable to everyone. Building on women's comparatively higher education and managerial experience, workshops could prepare them to play a critical role as households weigh the costs and benefits of adopting CA components. Determining and communicating the short-term economic benefits of CAPS and putting it in the context of the gendered division of labor could increase the likelihood of adoption by smallholder farmers. Researchers and extension agents could re-focus their priority from smallholder farmers to farmers whose access and control of land may be the larger constraint when it comes to development interventions. Including a restitution event as part of the research could also help to ground-truth findings and increase trust between researchers and participants, both of which can form the basis for ongoing and mutually beneficial collaboration.

Acknowledgments This research was made possible by the generous support of the American people through the U. S. Agency for International Development (USAID) and The Feed the Future Innovation Lab for Collaborative Research on Sustainable Agriculture and Natural Resource Management (SANREM) under the cooperative agreement number EPP-A00-04 00013-00. A special thanks to Dr. Jun Mercado (ICRAFPhilippines), Dr. Manny Reyes (NC A\&T), and Dr. Victor Ella 
(UPLB) for their substantial support of this research. A special thank you to the anonymous reviewer for their valuable comments on the manuscript.

Open Access This article is distributed under the terms of the Creative Commons Attribution License which permits any use, distribution, and reproduction in any medium, provided the original author(s) and the source are credited.

\section{References}

Allison, E. H., \& Ellis, F. (2001). The livelihoods approach and management of small-scale fisheries. Marine Policy, 25(5), 377-388.

Barrett, C. B. (2002). Food security and food assistance programs. Handbook of Agricultural Economics, 2(B), 2103-2190.

Basch, G., Geraghty, J., Stret, B., \& Sturny, W. (2008). Notillage in Europe-state of the art: Constraints and perspective. No-Till Farming Systems, 3, 159-168.

Bebbington, A. (1999). Capitals and capabilities: A framework for analyzing peasant viability, rural livelihoods and poverty. World Development, 27(12), 2022-2044.

Cramb, R. A. (2001). Soil conservation technologies for smallholding farming systems in the Philippines uplands: A socioeconomic evaluation Canerra. Australia: ACIAR.

Delgado, M., \& Canters, R. (2011). Measuring the accessibility of different household income groups to basic community services in upland Misamis Oriental, Northern Mindanao, Philippines. Singapore Journal of Tropical Geography, 32(2), 168-184.

Derpsch, R., Friedrich, T., Kassam, A., \& Li, H. (2010). Current status of adoption of no-till farming in the world and some of its main benefits. International Journal of Agricultural and Biological Engineering, 3(1), 1-25.

Doss, C. R., \& Morris, M. L. (2000). How does gender affect the adoption of agricultural innovations? Agricultural Economics, 25(1), 27-39.

Eder, J. F. (2006). Gender relations and household economic planning in the rural Philippines. Journal of Southeast Asian Studies, 37(3), 397.

Ellis, F. (2000). Rural livelihoods and diversity in developing countries. Oxford: Oxford University Press.

Estudillo, J., Quisumbing, A., \& Otsuka, K. (2001). Gender differences in land inheritance, schooling and lifetime income: Evidence from the rural Philippines. The Journal of Development Studies, 37(4), 23-48. doi:10.1080/ 00220380412331322031.

FAO. (Ed.). (2011). Gains from closing the gender gap. The State of Food \& Agriculture (vol. 16, pp. 1-160). Rome, Italy.

Feldman, S., \& Welsh, R. (1995). Feminist knowledge claims, local knowledge, and gender divisions of agricultural labor: Constructing a successor science 1. Rural Sociology, 60(1), 23-43.

Gebremedhin, B., \& Swinton, S. M. (2003). Investment in soil conservation in northern Ethiopia: The role of land tenure security and public programs. Agricultural Economics, 29(1), 69-84. doi:10.1016/S0169-5150(03)00022-7.

Giller, K. E. (2009). Conservation agriculture and smallholder farming in Africa: The heretics' view. Field Crops Research, . doi:10.1016/j.fcr.2009.06.017.

Giller, K. E., Witter, E., Corbeels, M., \& Tittonell, P. (2009). Conservation agriculture and smallholder farming in Africa: The heretics' view. Field Crops Research, 114(1), 23-34. doi:10.1016/j.fcr.2009.06.017.

Hobbs, P. R. (2007). Conservation agriculture: What is it and why is it important for future sustainable food production? Journal of Agricultural Science, 145(2), 127.

Hobbs, P. R., Sayre, K., \& Gupta, R. (2008). The role of conservation agriculture in sustainable agriculture. Philosophical Transactions of the Royal Society B: Biological Sciences, 363(1491), 543-555.

IFAD. (2009). Smallholder farming in transforming economies of Asia and the Pacific: Challenges and opportunities. Rome, Italy: IFAD.

Jones, S. (2002). A framework for understanding on-farm environmental degradation and constraints to the adoption of soil conservation measures: case studies from highland Tanzania and Thailand. World Development, 30(9), 1607-1620.

Kassam, A., Friedrich, T., Shaxson, F., \& Pretty, J. (2009). The spread of conservation agriculture: Justification, sustainability and uptake. International Journal of Agricultural Sustainability, 7(4), 292-320.

Knowler, D., \& Bradshaw, B. (2007). Farmers' adoption of conservation agriculture: A review and synthesis of recent research. Food Policy, 32(1), 25-48. doi:10.1016/j. foodpol.2006.01.003.

Magcale-Macandog, D., Rañola, F., Rañola, R., Ani, P., \& Vidal, N. (2010). Enhancing the food security of upland farming households through agroforestry in Claveria, Misamis Oriental, Philippines. Agroforestry Systems, 79(3), 327-342. doi:10.1007/s10457-009-9267-1.

Marshall, M. N. (1996). Sampling for qualitative research. Family Practice, 13(6), 522-526.

Mercado Jr., A., Tulin, A., Dorahy, C., Gilkes, R., \& Prakongkep, N. (2010). Soil management and crop nutrition for tomato in acid soil of Claveria, Philippines. In Proceedings of the 19th World Congress of Soil Science: Soil solutions for a changing world, (pp. 270-273). Brisbane, Australia. International Union of Soil Sciences (IUSS).

Mohanty, C. T. (2003). Feminism without borders: Decolonizing theory, practicing solidarity. Durham: Duke University Press.

Momsen, J. H. (2010). Introduction: Gender is a development issue. In Gender and Development (2nd ed., pp. 1-19). New York and Abingdon/UK: Routledge.

Nazarea, V. D. (1995). Local knowledge and agricultural decision making in the Philippines: Class, gender, and resistance (Food systems and agrarian change). Ithaca, NY: Cornell University Press.

Niehof, A. (2004). The significant of diversification for rural livelihood systems. Food Policy, 29(4), 321-338. doi:10. 1016/j.foodpol.2004.07.009.

Oberhauser, A. M., Mandel, J. L., \& Hapke, H. M. (2004). Gendered livelihoods in diverse global contexts: An 
introduction. Gender, Place \& Culture, 11(2), 205-208. doi:10.1080/0966369042000218455.

Olano, J. N. D. (2002). Land conflict resolution: Case studies in the Philippines. In Land Reform. Washington, DC: Food and Agriculture Organization.

Rocheleau, D., \& Edmunds, D. (1997). Women, men and trees: Gender, power and property in forest and agrarian landscapes. World Development, 25(8), 1351-1371.

Rocheleau, D., Thomas-Slayter, B., \& Wangari, E. (1996a). Gender and environment: A feminist political ecology perspective. New York: Routledge.

Rocheleau, D. E., Thomas-Slayter, B. P., \& Wangari, E. (1996b). Feminist political ecology: Global issues and local experiences. New York: Routledge.

Rubin, D., Manfre, C., \& Barrett, K. N. (2009). Promoting gender equitable opportunities in agricultural value chains: A handbook. Resource Document. United States Agency for International Development. http://transition.usaid.gov/
our_work/cross-cutting_programs/wid/pubs/GATE_ Gender_Ag_Value_Chain_Handbook_summary_1109.pdf. Accessed 9 Aug 2011.

Soule, M. J., Tegene, A., \& Wiebe, K. D. (2000). Land tenure and the adoption of conservation practices. American Journal of Agricultural Economics, 82(4), 993-1005. doi:10.1111/0002-9092.00097.

Tisch, S., \& Paris, T. (1994). Labor substitution in Philippine rice farming systems: An analysis of gender work roles 1. Rural Sociology, 59(3), 497-514.

Udry, C. (1996). Gender, agricultural production, and the theory of the household. The Journal of Political Economy, 104(5), 1010-1046.

Valdivia, C., \& Gilles, J. (2001). Gender and resource management: Households and groups, strategies and transitions. Agriculture and Human Values, 18(1), 5-9.

World Bank. (2009). Gender in agriculture sourcebook. Washington, DC: The World Bank. 